\title{
STATUS GIZI BALITA
}

\author{
DIAN YULIAWATI DARWIS
}

Universitas Islam Negeri Alauddin Makassar

Email: dianyuliawati33@gmail.com

\section{A. PENGERTIAN BALITA}

Balita adalah anak yang telah menginjak usia di atas satu tahun atau lebih popular dengan pengertian anak dibawah lima tahun. Balita adalah istilah umum bagi anak usia 1-3 tahun (batita) dan anak prasekolah (3-5 tahun). Saat usia batita, anak masih tergantung penuh kepada orang tua untuk melakukan kegiatan penting seperti mandi, buang air dan makan. Perkembangan berbicara dan berjalan sudah bertambah baik. Namun, kemampuan lain masih terbatas. Masa balita merupakan periode penting dalam proses tumbuh kembang manusia. Perkembangan dan pertumbuhan dimasa itu menjadi penentu keberhasilan pertumbuhan dan perkembangan anak di periode selanjutnya.

\section{B. PENGERTIAN STATUS GIZI}

Status gizi adalah keadaan gizi seseorang yang dapat dilihat untuk mengetahui apakah seseorang tersebut itu normal atau bermasalah (gizi salah). Gizi salah adalah gangguan kesehatan yang disebabkan oleh kekurangan atau kelebihan dan atau keseimbangan zat-zat gizi yang diperlukan untuk pertumbuhan, kecerdasan dan aktivitas atau produktivitas. Status gizi juga dapat merupakan hasil akhir dari keseimbangan antara makanan yang dimasukkan ke dalam tubuh (nutrient input) dengan kebutuhan tubuh (nutrient output) akan zat gizi tersebut.

\section{PENILAIAN STATUS GIZI SECARA LANGSUNG}

\section{1.) Antropometri}

Secara umum antropometri artinya ukuran tubuh manusia. Ditinjau dari sudut pandang gizi antropometri gizi berhubungan dengan berbagai macam pengukuran dimensi tubuh dan komposisi tubuh dari berbagai tingkat umum dan tingkat gizi. Pengukuran melalui antropometri mempunyai kelebihan dari beberapa segi kepraktisan lapangan. Pengukuran 
antropometri yang biasa dilakukan adalah Berat Badan (BB), Panjang Badan (PB), Tinggi Badan (TB), dan Lingkar Lengan Atas (LLA).

2.) Klinis

Pemeriksaan klinis adalah metode yang sangat penting untuk menilai status gizi masyarakat.Metode ini berdasarkan atas perubahan-perubahan yang terjadi yang dihubungkan dengan ketidakcukupan zat gizi. Hal ini dapat dilihat pada jaringan epitel (supervicial epithelial tissues) seperti kulit, mata, rambut dan mukosa oral/pada organorgan yang dekat dengan permukaan tubuh seperti kelenjar tiroid.

3.) Biokimia

Penilaian status gizi dengan biokimia adalah pemeriksaan yang diuji secara laboratorium yang dilakukan pada berbagai macam jaringan tubuh. Jaringan tubuh yang digunakan antara lain : darah, urine, tinja dan beberapa jaringan tubuh seperti hati dan otot.

4.) Biofisik

Penilaian status gizi baik secara biofisik adalah metode penentuan status gizi dengan menilai kemampuan fungsi (khususnya jaringan) dan melihat perubahan struktur dari jaringan.

\section{PENILAIAN STATUS GIZI SECARA TIDAK LANGSUNG}

1.) Survei Konsumsi Makanan

Survei konsumsi makanan adalah metode penentuan status gizi secara tidak langsung dengan melihat jumlah dan jenis zat gizi yang dikonsumsi.

2.) Statistik Vital

Penilaian status gizi dengan statistik vital adalah menganalisis data beberapa statistik kesehatan seperti angka kematian berdasarkan umur, angka kesakitan dan kematian akibat penyebab tertentu dan data lainnya yang berhubungan dengan gizi.

3.) Faktor Ekologi

Bengoa dalam Supariasa mengungkapkan bahwa malnutrisi merupakan masalah ekologi sebagai hasil interaksi beberapa faktor fisik, biologis dan lingkungan budaya. Jumlah makanan yang tersedia sangat tergantung dari keadaan ekologi seperti iklim, tanah, irigasi dan lain-lain. 


\section{E. FAKTOR LANGSUNG YANG MEMPENGARUHI STATUS GIZI}

1.) Faktor infeksi

Defisiensi gizi sering dihubungkan dengan infeksi. Infeksi bisa dihubungkan dengan gangguan gizi melalui beberapa cara yaitu mempengaruhi nafsu makan, dapat juga menyebabkan kehilangan bahan makanan karena diare atau muntah mempengaruhi metabolisme makanan dan banyak cara lain lagi. Secara umum, defisiensi gizi merupakan awal dari gangguan sistem kekebalan. Gizi kurang dan infeksi, kedua-duanya dapat bermula dari kemiskinan dan lingkungan tidak sehat dengan sanitasi yang buruk.Selain itu juga diketahui bahwa infeksi menghambat reaksi immunologis yang normal dengan menghasilkan sumber-sumber energi tubuh. Gangguan gizi dan infeksi sering bekerja sama dan jika bekerja sama akan memberikan prognosis yang lebih buruk jika dibandingkan dengan jika kedua faktor tadi bekerja sendiri-sendiri. Infeksi memperburuk taraf gizi dan sebaliknya, gangguan gizi memperburuk kemampuan anak untuk mengatasi penyakit infeksi. Kuman-kuman yang kurang berbahaya bagi anak-anak dengan status gizi naik, bisa menyebabkan kematian pada anak-anak dengan status gizi yang buruk.

\section{2.) Asupan Makanan}

Tujuan memberi makan pada anak adalah untuk memenuhi kebutuhan zat gizi yang cukup dalam kelangsungan hidupnya, pemulihan kesehatan sesudah sakit, untuk aktivitas pertumbuhan dan perkembangan. Dengan memberikan makan anak juga didik agar dapat menerima, menyukai makanan yang baik serta menentukan jumlah makanan yang cukup dan bermutu.

Makanan sehari-hari yang dipilih dengan baik akan memberikan semua zat gizi yang dibutuhkan untuk fungsi normal tubuh. Sebaliknya, jika makanan tidak dipilih dengan baik, tubuh akan mengalami kekurangan zat-zat gizi esensial tertentu. Konsumsi aneka ragam makanan merupakan salah satu cara untuk mencukupi zat-zat gizi yang kurang di dalam tubuh

\section{F. FAKTOR TIDAK LANGSUNG YANG MEMPENGARUHI STATUS GIZI}

1.) Pola Asuh

Pola asuh adalah praktek di rumah tangga yang diwujudkan dengan tersedianya pangan dan perawatan kesehatan serta sumber lainnya untuk kelangsungan hidup, pertumbuhan 
dan perkembangan anak (LIPI, 2000 ). Pola pengasuhan anak berupa sikap dan perilaku ibu atau pengasuh lain dalam hal hakekatnya dengan anak, memberikan makan, merawat, kebersihan, memberi kasih sayang dan sebagainya. Kesemuanya berhubungan dengan keadaan ibu dalam hal kesehatan (fisik dan mental), status gizi, pendidikan umum, pengetahuan dan keterampilan, tentang pengasuhan anak yang baik, peran dalam keluarga atau di masyarakat, sifat pekerjaan sehari-hari, adat kebiasaan keluarga dan masyarakat, dan sebagainya dar si ibu atau pengasuh anak

2.) Pengetahuan

Kurangnya pengetahuan tentang gizi atau kemampuan untuk menetapkan informasi dalam kehidupan sehari-hari merupakan penyebab terjadinya gangguan gizi. Ibu yang mempunyai pengetahuan gizi dan kesadaran gizi yang tinggi akan melatih kebiasaan makan yang sehat sedini mungkin kepada semua putra-putrinya. Selain itu tingkat pengetahuan ibu sebagai pengelola rumah tangga akan berpengaruh juga pada macam bahan makanan dalam konsumsi keluarga sehari-hari. Ibu yang cukup pengetahuan gizinya akan memperhatikan kebutuhan gizi anaknya agar dapat tumbuh dan berkembang secara optimal.

Pengetahuan ibu memberi makan anak sering menghadapi kesulitan dan juga pengetahuanibu tentang cara memperlakukan bahan pangan dalam pengelolaan sehingga zat gizi yang terkandung di dalamnya tidak rusak atau salah masih perlu dikajidi pedesaan.

\section{3.) Sikap}

Sikap merupakan reaksi atau respon yang masih tertutup dari seseorang terhadap stimulus atau objek. Manifestasi sikap itu tidak dapat langsung dilihat, tetapi hanya dapat ditafsirkan terlebih dahulu dari perilaku yang tertutup. Suatu sikap belum dapat otomatis terwujud dalam suatu tindakan (over behaviour). Banyak factor yang dapat mempengaruhi penentuan sikap secara utuh seperti pengetahuan, berfikir, berkeyakinan, dan emosi itu semua memegang peranan sangat penting. Sedangkan untuk mewujudkan sikap menjadi suatu perbuatan nyata diperlukan faktor pendukung atau kondisi yang memungkinkan antara lain adalah fasilitas.

\section{4.) Perilaku}


Komponen perilaku atau komponen konatif dalam struktur sikap menunjukkan bagaimana perilaku atau kecenderungan berperilaku yang ada dalam diri seseorang berkaitan dengan objek sikap yang dihadapinya. Kaitan ini didasari oleh asumsi bahwa kepercayaan dan perasaan banyak mempengaruhi perilaku. Maksudnya, bagaimana orang berperilaku dalam situasi tertentu dan terhadap stimulus tertentu. Kecenderungan berperilaku secara konsisten, selaras dengan kepercayaan dan perasaan ini membentuk sikap individual. Karena itu, adalah logis untuk mengharapkan bahwa sikap seseorang akan dicerminkannya dalam bentuk tendensi perilaku terhadap objek.

\section{G. FAKTOR YANG BERHUBUNGAN DENGAN KEJADIAN STUNTING PADA BALITA DI WILAYAH KERJA PUSKESMAS PANNAMBUNGAN KOTA MAKASSAR}

Stunting adalah kondisi dimana balita memiliki panjang atau tinggi badan yang kurang jika di bandingkan dengan anak seusianya. Kondisi ini diukur dengan panjang atau tinggi badan yang lebih dari mines 2 standar devisi (sd) median standar pertumbuhan anak dari world health organization. Balita stunting termasuk masalah gizi kronik yang disebabkan oleh banyak faktor seperti kondisi sosial ekonomi, gizi ibu saat hamil, dan kurangnya asupan gizi pada bayi. Balita stunting dimasa yang akan datang akan mengalami kesulitan dalam mencapai perkembangan fisik dan kognitif yang optimal.

Stunting (pendek) merupakan keadaan tumbuh kembang anak pada 1000 hari pertama kehidupan (HPK) yang diakibatkan oleh kekurangan gizi secara kronik. Anak dapat di katakan stunting, jika kondisi panjang atau tinggi badan balita yang tidak sesuai dengan umur, berbeda dengan tinggi badan seumurannya. Kondisi ini dapat di ukur dengan standar pertumbuhan anak dariworld Health Organization (WHO) yaitu mengukur Panjang atau tinggi badan anak yang di bawah minus dua standar deviasi median maka di katakan stunting. WHO menyatakan stunting menjadi permasalahan kesehatan jika prevalensi mencapai $\geq 20 \%$.

\section{Hubungan Pengetahuan Ibu dengan Kejadian Stunting}

Pengetahuan adalah hasil pengindraan manusia, atau hasil tahu seseorang terhadap objek melalui indra yang di milikinya (mata, hidung, telinga, mulut, dan kulit). Pengetahuan atau 
ranah kognitif merupakan domain yang sangat penting dalam membentuk tindakan seseorang overt behavior.

Pengetahuan ibu tentang gizi merupakan faktor resiko kejadian stunting yang bermakna. Pengetahuan akan menentukan perilaku ibu dalam menyediakan makanan dengan jenis dan jumlah yang tepat agar anaknya dapat bertumbuh dan berkembang secara optimal (Round dan Margawati ,2012). Pengetahuan gizi yang tidak memadai kurangnya pengertian tentang kebiasaan makan yang baik, serta pengertian tentang konstribusi gizi dari berbagai jenis makanan akan menimbulkan masalah gizi (Wulandari dan Indra, 2013).Penyediaan bahan dan menu makanan yang tepat untuk balita dalam upaya peningkatan status gizi akan dapat terwujud bila ibu mempunyai tingkat pengetahuan gizi yang baik..ketidaktahuan mengenai informasi tentang gizi dapat menyebabkan kurangnya mutu atau kualitas gizi makanan bagi keluarga khususnya bagi makanan makanan yang dikonsumsi balita (Sjahmien,2003).

Salah satu penyebab gangguan gizi adalah kurangnya pengetahuan gizi dan kemampuan seorang menerapkan informasi tentang gizi dalam kehidupan sehari-hari. Tingkat pengetahuan gizi ibu mempengaruhi sikap dan perilaku dalam memilih bahan makanan, yang lebih lanjut akan mempengaruhi keadaan gizi keluarganya (Suhardjo,2003).

Pengetahuan Ibu yang rendah dapat berdampak pada sikap dan prilaku Ibu dalam memberikan makanan kepada balita, yang menimbulkan ketidakseimbanganmakanan bergizi yang dibutuhkan balita yang sangat penting dalam masa pertumbuhan, sehingga menyebabkan balita mempunyai status gizi kurang. Namun pada balita yang mempunyai gizi baik pun Ibu juga memiliki tingkat pengetahuan yang rendah tentang status gizi.hal ini mungkin di karenakan balita sering di asu oleh nenek atau pengasunya yang jauh memiliki pengetahuan yang lebih baik tentang gizi di bandingkan Ibu,sehingga balita tetap dapat terpenuhi gizi dengan baik meskipun ibunya sendiri rendah pengetahuannya tentang gizi.

\section{Hubungan Pendapatan Keluarga dengan Kejadian Stunting}

Menurut Sihadi (2006) bahwah tingkat pendapatan ikut menentukan jenis pangan apa yang akan di beli dengan adanya tambahan uang, Semakin tinggi pendapatan,semakin besar pulah peresentase dari penghasilan tersebut dipergunakan untuk membeli berbagai jenis bahan pangan. Jadi pendapatan merupakan faktor penting bagi kuantitas dan kualitas makan dalam keluarga. perubahan pendapatan dapat mempengaruhi perubahan pola asu gizi yang 
secara langsung mempengaruhi konsumsi pangan pada balita. Meningatnya pendapatan berarti memperbesar peluang untuk membeli pangan dengan kualitas dan kuantitas yang lebih baik. Sebaliknya, pendapatan yang rendah akan meyebabkan penurunan dalam hal kualitas dan penurunan kuantitas pangan yang dibeli dan makanan yang dikonsumsi tidak mempertimbangkan nilai gizi, tetapi nilai materi lebi mejadi pertimbangan. Terdapat dua perubahan ekonomi yang cukup dominan sebagai determinan pola asu gizi yaitu pendapatan keluarga dan harga pangan.

Tingkat pendapatan yang cukup, maka ibu lebih leluas untuk memilih dan membeli kebutuhan bayi seperti membeli daging sapi, ikan, buah meskipun harga di pasar cukup mahal. Namun sebaliknya, ibu yang tidak mempunyai pendapatan yang cukup, maka akan kesulitan memberikan asupan gizi yang baik kepada bayi dimana ibu hanya memberikan sayur dan lauk dengan menu yang jarang berfariasi sehingga menjadikan bayi dengan gizi kurang meskipun tingkat pendapatan kluarga diatas UMK namun, masih ditemukan balita dengan gizi kurang.

Hal ini dapat dipengaruh faktor lain seperti jumlah anggota keluarga yang ditanggung lebih besar, artinya semakin banyak anggota keluarga yang ditanggung maka semakin banyak pengeluaran biaya untuk mencukupi kebutuhan gizi keluarga, sementara disisi lain pendapatan keluarga per bulan dapat dianggap tetap namun harga bahan makanan yang cendrung. Faktor-faktor tersebut harus menjadi perhatian oleh pemerintah.

\section{Hubungan Berat Badan Lahir Rendah (BBLR) dengan Kejadian Stunting}

Berat Badan Lahir Rendah (BBLR) yaitu berat badan bayi kurang dari 2500 geram. Selama masa kehamilan, pertumbuhan embrio dan janin berlansung sangat cepat, mulai kurang satu mili gram menjadi sekitar 3000 geram. Pertumbuhan yang cepat ini sangat penting untuk janin agar dapat bertahan hidup ketika berada diluar rahim. Jadi, kecacatan atau kekuranagan yang terjadi pada masa janin merupakan penyebab utama redahnya kesehatan dan kematian pada bayi (Oktarina, 2012).

Berat badan lahir sangat terkait dengan pertumbuhan dan perkembangan jangka panjang anak balita, pada penelitian yang dilakukan oleh Anisa (2012) menyimpulkan bahwa terdapat hubungan yang bermakna antara berat lahir dengan kejadian stunting pada balita . Bayi yang 
lahir dengan berat badan lahir rendah (BBLR) akan mengalami hambatan pada pertumbuhan dan perkembangan serta kemungkinan terjadi kemunduran fungsi intelektualnya.

\section{Hubungan Pola Makan dengan Kejadian Stunting}

Pola makan pada balita sangat berperan penting dalam proses pertumbuhan pada balita, karena dalam makanan banyak mengandung gizi. Gizi menjadi bagian yang sangat penting dalam pertumbuhan. Gizi didalamnya memiliki keterkaitan yang sangat erat hubungannya dengan kesehatan dan kecerdasan. Jika pola makan tidak tercapai dengan baik pada balita maka pertumbuhan balita akan terganggu, tubuh kurus, pendek bahkan bisa terjadi gizi buruk pada balita. Stunting sangat erat kaitannya dengan pola pemberian makanan terutama pada 2 tahun pertama kehidupan, pola pemberian makanan dapat mempengaruhi kualitas konsumsi makanan balita, sehingga dapat mempengaruhi status gizi balita.

Pemberian ASI yang kurang dari 6 bulan dan MP-ASI terlalu dini dapat meningkatkan risiko stunting karena saluran pencernaan bayi belum sempurna sehingga lebih mudah terkena penyakit infeksi seperti diare dan ISPA. Pola pemberian makanan anak balita terdiri dari tingkat asupan makanan dan frekuensi pemberian makanan.

\section{H. HUBUNGAN SOSIAL BUDAYA DENGAN KEJADIAN STUNTING PADA BALITA USIA 24-59 BULAN DI DESA BONE-BONE KECAMATAN BARAKA KABUPATEN ENREKANG TAHUN 2020}

Stunting adalah masalah kurang gizi kronis yang disebabkan oleh asupan gizi yang kurang dalam waktu cukup lama akibat pemberian makanan yang tidak sesuai dengan kebutuhan gizi. Stunting terjadimulai janin masih dalam kandungan.Stunting merupakan salah satu masalah gizi yang berdampak buruk terhadap kualitas hidup anak dalam mencapai titik tumbuh kembang yang optimal sesuai potensi genetiknya. Stunting dapat menghambat proses tumbuh kembang pada balita.

Balita usia 24-59 bulan termasuk dalam golongan masyarakat kelompok rentan gizi (kelompok masyarakat yang paling mudah menderita kelainan gizi), sedangkan pada saat itu mereka sedang mengalami proses pertumbuhan yang relatif pesat (Ratih, 2014). Gangguan pertumbuhan linear atau stunting, terjadi terutama dalam 2 sampai 3 tahun pertama 
kehidupan dan merupakan cerminan dari efek interaksi antara kurangnya asupan energi dan asupan gizi, serta infeksi.

\section{Hubungan Sosial Budaya dengan Kejadian Stunting}

Berdasarkan hasil bivariat dengan menggunakan uji Chi-Square diperolehhasil $\mathrm{p}=0,281$ ( $p>0,05)$ yang berarti bahwa tidak ada hubungan yang signifikan antara sosial budaya dengan kejadian stunting. Pada hasil penelitian ini yang termasuk dalam kategori baik pada aspek sosial budaya menunjukkan 23 balita $(76,7 . \%)$ mengalami stunting dan sebanyak 7 balita $(23,3 \%)$ tidak mengalami stunting. Sedangkan pada kategori kurang pada aspek sosial budaya ditemukan 2 balita $(50,0 \%)$ yang mengalami stunting dan 2 balita $(50,0 \%)$ tidak mengalami stunting.

Walaupun hasil penelitian ini menunjukkan tidak ada hubungan, ternyata setelah diliat dari pola asuh khususnya praktik pemberian makan pada balita masih ada ibu yang memberikan makanan pendamping ASI (MP-ASI) sebelum umur 6 bulan.Ini menggambarkan bahwa ibu sudah mengetahui pemberian MP ASI sebelum 6 bulan itu tidak benar, namun secara praktik itu tidak dilakukan. Berdasarkan hasil wawancara diketahui bawa ibu yang memberikan MP ASI sebelum 6 bulan diakibatkan karena ibu yang juga merupakan seorang petani sehinnga waktu untuk menyusui kurang dan solusinya adalah pemberian susu formula. ASI eksklusif dapat mempengaruhi kejadian stunting karena jika bayi yang belum cukup umur 6 bulan sudah diberi makanan selain ASI akan menyebabkan usus bayi tidak mampu mencerna makanan dan bayi akan mudah terkena penyakit karena kurangya asupan. Sehingga balita yang sering menderita penyakit infeksi akan menyebabkan pertumubuhannya terhambat dan tidak dapat mencapai pertumbuhan yang optimal (Nurjannah, 2019).

\section{Hubungan Kepercayaan Makanan dengan Kejadian Stunting}

Berdasarkan hasil bivariat dengan menggunakan uji Chi-Square diperoleh hasil p=0,089 $(\mathrm{p}<0,05)$ yang berarti bahwa tidak ada hubungan yang signifikan antara kepercayaan makanan dengan kejadian stunting. Pada hasil penelitian ini menunjukkan bahwa semua balita yang memiliki pantangan makanan mengalami stunting, sedangkan yang tidak 
memiliki pantangan makanan 19 balita (70,4\%) menalami stunting dan $8(29,6 \%)$ balita tidak mengalami stunting.

Namun beberapa jenis makan yang dipantangkan kepada anak tersebut dikarenakan alasan kesehatan seperti gatal-gatal, sehingga orang tua tidak membrikan makanan tersebut walaupun mempunyai nilai gizi yang tinggi dan dibutuhkan oleh anak dalam proses tumbuh kembangnya. Oleh karena itu orang tua harus mencari opsi atau makanan lain yang memiliki nilai gizi yang setara sehingga mampu mencegah anak mengalami stunting.

\section{Hubungan Dukungan Keluarga Dengan Kejadian Stunting}

Berdasarkan hasil bivariat dengan menggunakan uji Chi-Square diperoleh hasil $\mathrm{p}=0,050$ $(\mathrm{p}<0,05)$ yang berarti bahwa ada hubungan yang signifikan antara dukungan keluarga dengan kejadian stunting. Pada hasil penelitian ini yang termasuk dalam kategori baik pada dukungan keluarga menunjukkan 12 balita (60,0.\%) mengalami stunting dan sebanyak 8 balita $(40,0 \%)$ tidak mengalami stunting. Sedangkan pada kategori kurang pada dukungan keluarga ditemukan 13 balita (92,9\%) mengalami stunting dan 1 balita $(7,1 \%)$ tidak mengalami stunting.

\section{Hubungan Pola Pengasuhan Balita Dengan Kejadian Stunting}

Berdasarkan hasil bivariat dengan menggunakan uji Chi-Square diperoleh hasil $\mathrm{p}=1.000$ ( $p>0,05)$ yang berarti bahwa tidak ada hubungan yang signifikan antara pengasuhan anak dengan kejadian stunting. Pada hasil penelitian ini yang termasuk dalam kategori baik pada pengasuhan anak menunjukkan 23 balita (71,9.\%) mengalami stunting dan sebanyak 9 balita $(28,1 \%)$ tidak mengalami stunting. Sedangkan pada kategori kurang pada pengasuhan anak ditemukan 2 balita (100\%) yang semunaya mengalami stunting.

Pola asuh ibu memiliki peran dalam kejadia stunting pada balita karena asupan makanan pada balita sepenuhnya diatur oleh ibunya. Ibu dengan pola asuh baik akan cenderung memiliki balita dengan status gizi yang lebih baik daripada ibu dengan pola asuh yang kurang. Namun dalam penelitian ini ibu dengan pola asuh yang baik belum tentu memiliki balita dengan masalah stunting yang lebih kecil daripada ibu dengan pola asuh yang kurang.Hal ini bisa jadi dikarenakan meskipun pola asuh ibu baik,pada keluarga miskin 
terdapat keterbatasan dalam memenuhi kebutuhan sehari-hari sehingga pola asuh ibu tidak memengaruhi terjadinya masalah stunting.

\section{HUBUNGAN BBLR, KEBIASAAN MEROKOK KELUAGA, DAN STATUS GIZI DENGAN RIWAYAT ISPBAYI DI KELURAHAN BALLAPARANG}

Penyakit Infeksi Saluran Pernafasan Akut (ISPA) merupakan penyakit saluran pernafasan yang sering di temui pada masyarakat, khususnya pada bayi dan balita di negara dengan pendapatan per kapita rendah dan menengah. Menurut masriadi (2017) ISPA adalah penyakit saluran pernafasan atas atau bawah yang menular dan menimbulkan bebagai spektrum penyakit yang berkisar dari penyakit tanpa gejala atau infeksi ringan hingga penyakit parah dan mematikan tergantung dari faktor yang ada. ISPA juga sering diartikan sebagai penyakit saluran pernafasan akut yang disebabkan oleh agen infeksius yang ditularkan dari manusia ke manusia lainnya. Gejala yang timbul biasanya cepat, hanya dalam waktu beberapa jam samapai beberapa hari. Gejala ISPA yaitu demam, batuk, nyeri tenggorokan, pilek, sesak napas, mengi,atau kesulitan bernapas (Aprilla, Nia.,dkk, 2019).

WHO mengatakan bahwa ISPA sebagai The Forgotten Killer Of Children karena sebagai pembunuh utama balita di dunia, 6,6 juta balita meninggal dunia. Maka target Rencana Aksi Program Pencegahan dan Pengendalian Penyakit 2015-2019 di Indonesia salah satunya untuk menurunkan kematian bayi dan balita dari 32 menjadi 24 per 1.000 kelahiran hidup (RAP P2P, 2018).

\section{Hubungan antara Berat Badan Lahir dengan riwayat ISPA Bayi}

Penelitian ini menunjukkan bahwa dari 27 bayi yang memiliki riwayat berat badan lahir rendah paling banyak yaitu 20 bayi yang mempunyai riwayat ISPA, artinya jika bayi memiliki riwayat berat badan lahir rendah lebih banyak maka bayi rentan terkena ISPA. Sedangkan, dari 39 bayi yang memiliki berat badan normal paling sedikit terdapat 6 bayi yang mempunyai riwayat ISPA, artinya jika bayi memiliki riwayat berat badan lahir normal maka tidak rentan terkena ISPA.

Hasil penelitian ini menunjukkan sejalan dengan teori diatas, dimana bayi yang dilahirkan dengan riwayat berat badan lahir rendah lebih banyak mempunyai riwayat ISPA dibandigkan dengan bayi yang mempunyai berat badan lahir normal. Penelitian ini sejalan 
dengan penelitian lain yang dilakukan oleh Firda (2015) yang menyatakan bahwa ada hubungan yang signifikan antara berat badan lahir dengan ISPA pada bayi dengan nilaip $=0,037(\mathrm{p}=<0,05)$.

\section{Hubungan antara Kebiasaan Merokok Keluarga dengan riwayat ISPA Bayi}

Hasil diatas menunjukkan bahwa dari 47 bayi yang keluarganya mempunyai kebiasaan merokok paling banyak yaitu 30 bayi yang mempunyai riwayat ISPA, artinya jika keluarga mempunyai kebiasaan merokok lebih banyak maka bayi rentan terkena ISPA. Sedangkan, dari 19 bayi yang keluarganya tidak mempunyai kebiasaan merokok paling sedikit terdapat 6 bayi yang mempunyai riwayat ISPA, artinya jika keluarga tidak mempunyai kebiasaan merokok maka tidak rentan terkena ISPA.

Hasil penelitian ini menunjukkan sejalan dengan teori diatas, dimana bayi yang mempunyai keluarga perokok memiliki riwayat ISPA dibandingkan dengan bayi yang mempunyai keluarga perokok. Penelitian ini sejalan dengan penelitian yang dilakukan oleh Fera siska (2019) yang menyatakan bahwa ada hubungan yang signifikan antara kebiasaan merokok di dalam rumah dengan riwayat ISPA pada bayi dan balita 0-5 tahun dengan diperkuat data hasil $100 \%$ yang didapatkan sebanyak 58,8\% bayi yang memiliki keluarga yang mempunyai kebiasaan merokok dalam rumah terkena ISPA dengan $p=0,007(p=<0,05)$.

\section{Hubungan antara Status Gizi (BB/U) dengan riwayat ISPA Bayi}

Status gizi yang baik dipengaruhi oleh banyak faktor salah satunya oleh jumlah asupan zat gizi yang dikonsumsi. Asupan gizi secara tidak langsung dipengaruhi oleh beberapa faktor salah satunya karakteristik keluarga. Hasil penelitian terdapat 7 bayi $(38,9 \%)$ yang berstatus gizi tidak normal, namun memiliki riwayat tidak ISPA. Hal ini disebabkan dari faktor-faktor lain diluardari status gizi contohnya faktor lingkungan, pengetahuan ibu, dan lain sebagainya.

Hasil penelitian ini menunjukkan tidak sejalan dengan teori diatas, dimana terdapat 25 bayi $(52,1 \%)$ yang normal/baik yang lebih banyak terkena ISPA. Sedangkan, terdapat 11 bayi $(61,1 \%)$ yang tidak normal lebih sedikit terkena ISPA. Pada kasus ini kemungkinan adafaktor lain yang lebih berperan seperti faktor ibu dan lingkungan sekitar. 


\section{J. HUBUNGAN TIPE POLA ASUH DAN PERILAKU MAKAN DENGAN STATUS GIZI ANAK DISABILITAS Di SLB NEGERI 1 MAKASSAR TAHUN 2020}

Anak disabilitas merupakan anak yang memiliki keterbatasan pada salah satu atau beberapa kemampuan baik bersifat fisik seperti tuna netra, maupun bersifat psikologis seperti autism dan ADHD (Susanti \& Yuni, 2019). Menurut Undang-Undang Republik Indonesia Nomor 8 tahun 2016 penyandang disabilitas merupakan seseorang yang memiliki keterbatasan secara fisik, mental, intelektual, dam sensorik dalam waktu yang lama dan mengalami kesulitan dalam berinteraksi dengan lingkungan maupun berpartisipasi secara efektif dengan warga Negara berdasarkan kesamaan hak. Beberapa jenis penyandang disabilitas yaitu tuna netra, tuna rungu, tuna wicara, tuna daksa, tunagrahita, tuna ganda, autis, lamban belajar, kesulitan belajar spesifik, attention deficit and hyperactivity disorder (ADHD), serta anak berbakat (Usop et al., 2019).

Berdasarkan data WHO 2018, terdapat lebih dari 1 miliar orang dari 7 miliar penduduk dunia hidup dengan keterbatasan fisik dan $80 \%$ penyandang disabilitas tinggal di negara berkembang. Terdapat lebih dari 100 juta anak-anak yang menyandang disabilitas (WHO, 2018). Proporsi disabilitas pada anak umur 5-17 tahun di Indonesia pada tahun 2018 sebesar 3,3\%. Prevalensi anak disabilitas tertinggi terdapat pada provinsi Sulawesi Tengah sebesar 7\% dan terendah terdapat pada provinsi Sulawesi Barat sebesar 1,4\%. Sedangkan, provinsi Sulawesi Selatan berada pada urutan ke-4 tertinggi sebesar 5,3\% (Kementrian Kesehatan Republik Indonesia, 2018).

\section{Hubungan Tipe Pola Asuh dengan Status Gizi}

Pola asuh pengabaian merupakan pola asuh yang memiliki aspek demandingness dan responsiveness rendah. Demandingness rendah menunjukkan kurangnya peran ibu dalam menuntut anak untuk makan. Sedangkan responsiveness rendah menunjukkan ibu kurang tanggap dalam memenuhi kebutuhan anak terkait makan. Sehingga, makanan yang dikonsumsi oleh anak dikendalikan sendiri oleh anak tanpa adanya kontrol atau kurangnya kontrol dari orang tua (Yumni, 2016).

Secara umum, pola pengasuhan dapat mempengaruhi status gizi anak khususnya pola asuh makan. Menurut Karyadi (1985), pola asuh makan didefinisikan sebagai praktek pengasuhan yang diterapkan ibu kepada anak yang berkaitan dengan cara dan situasi makan 
(Isnaina, 2019). Jumlah dan kualitas makanan yang dibutuhkan untuk konsumsi anak perlu dipikirkan dan direncanakan karena dapat memberikan pengaruh yang besar terhadap keadaan status gizi anak (Indriyani, 2015). Namun pada penelitian ini, kuesioner yang digunakan kurang menggambarkan apakah orang tua juga mengontrol jumlah asupan makanan anak maupun jenis makanan yang dikonsumsi.

\section{Hubungan Perilaku Makan dengan Status Gizi}

Dari hasil analisis chi-square didapatkan nilai $\mathrm{p}=0,004<0,05$ menyatakan bahwa HOditolak dan Ha diterima yang berarti terdapat hubungan yang signifikan antara perilaku makan dengan status gizi anak disabilitas di SLB Negeri 1 Makassar. Hal ini sejalan dengan penelitian yang dilakukan oleh Utari (2017) mengenai perilaku makan anak, diperoleh nilai p $=0,001<0,05$ yang berarti terdapat hubungan yang bermakna antara perilaku makan anak dengan status gizi.

Perilaku makan pada anak berperan penting terhadap status gizi termasuk kejadian status gizi kurang dan status gizi lebih, seperti pada hasil penelitian yang telah dilakukan menunjukkan kecenderungan siswa yang memiliki status gizi lebih memiliki perilaku makan yaitu penyuka makanan. Perilaku penyuka makanan yang tinggi dapat memberikan dampak yang kurang baik terhadap kondisi kesehatan khususnya dari segi status gizi yang menyebabkan anak mengalami gizi lebih (Yumni, 2016).

Sedangkan pada anak dengan disabilitas autis lebih cenderung memiliki perilaku makan yang kurang baik dan cendenrung mengalami gizi kurang. Hal ini disebabkan karena anak autis menyukai makanan yang terbatas akan gizi dan tidak menyukai beberapa jenis sayuran akibat keterbatasan dalam mencerna, menyerap, dan memfungsikan nutrisi yang masuk ke dalam tubuhnya dengan baik. Penyebab lainnya, penderita autis tidak dapat mengonsumsi makanan yang mengandung gluten dan kasein sehingga asupan gizi anak autis tidak dapat tercukupi dengan baik.

\section{K. HUBUNGAN POLA MAKAN DAN RIWAYAT ASI EKSLUSIF KEJADIAN STUNTING PADA BALITA DI KABUPATEN GORONTALO}

Menurut Riset Kesehatan Dasar (Riskesdas) tahun 2018, prevalensi underweight, stunting, wasting berturut-turut adalah 17,7 persen; 30,8 persen; dan 10,2 persen. Indonesia 
merupakan salah satu negara dengan prevalensi stunting cukup tinggi dibandingkan negaranegara berpendapatan menengah lainnya. Riskesdas tahun 2018 melaporkan prevalensi stunting dari tahun 2013 ke tahun 2018 mengalami penurunan sebesar 6,4 persen(Kemenkes, 2018).

Kurang gizi yang terjadi pada awal masa kanak-kanak memiliki konsekuensi yang serius. Anak yang mengalami gizi kurang cenderung mengalami sakit yang lebih parah. Terdapat hubungan kuat antara kurus pada anak dengan kematian pada anak. Kurus pada anak Balita menyumbang kematian sebesar 4,7 persen atau 2 juta kematian dari seluruh kematian anak Balita di dunia. Anak kurang gizi yang lolos dari kematian akan menjadi dewasa yang pendek, memiliki IQ yang lebih rendah, terhambat produktivitas ekonominya dan berisiko lebih besar memiliki keturunan dengan berat badan yang kurang. Anak yang terlahir dengan berat badan rendah dan berlanjut menderita gizi kurang pada masa kanakkanaknya akan tumbuh menjadi dewasa dengan risiko lebih besar untuk memiliki glukosa darah, tekanan darah dan lipid darah yang tinggi (PSG, 2017)

\section{Asupan Protein dengan kejadian Stunting}

Hasil recall 24 menunjukkan 82 (52,9\%) anak memiliki asupan protein yang kurang dan mengalami stunting, $24(11,17 \%)$ anak memiliki asupan protein yang cukup. Hasil penelitian menunjukkan ada hubungan asupan protein dengan kejadian stunting dengan nilai pvalue $0,000(\mathrm{p}<0,05)$.

\section{Riwayat ASI Ekslusif}

Hasil penelitian menunjukkan bahwa tidak ada hubungan antara riwayat Asi Ekslusif dengan kejadian stunting pada balita dimana uji chi square memperlihatkan nilai $\mathrm{p}$ value $=0,965 \leq \alpha 0,05$. Sebanyak $89(30,4 \%)$ anak balita yang tidak mendapatka asi ekslusif dan 17 (25,3\%) anak balita yang mendapatkan asi ekslusif.

Penelitian ini sejalan Indriyati et al., (2020) mengemukakan bahwa ASI eksklusif tidak berperan sebagai faktor risiko balita stunting karena faktor langsung dari masalah gizi adalah asupan nutrisi yang dikonsumsi oleh anak, sehingga apabila balita mendapatkan asupan nutrisi yang cukup sesuai dengan kebutuhan walaupun bayi tidak mendapatkan ASI eksklusif maka anak dapat tumbuh dengan baik. 


\section{DAFTAR PUSTAKA}

1. Sudarman, S., Aswadi., Muharti Syamsul., \& Margareta Gabut. 2021. Hubungan Tipe Pola Asuh dan Perilaku Makan dengan Status Gizi Anak Disabilitas Di SLB Negeri 1 Makassar Tahun 2020.

2. Ibrahim, I., Syamsul Alam., Andi Syamsiah Adha., Yusma Indah Jayadi., \& Muhammad Fadlan. 2021. Hubungan Sosial Budaya Dengan Kejadian Stunting Pada Balita Usia 24 59 Bulan Di Desa Bone-Bone Kecamatan Baraka Kabupaten Enrekang Tahun 2020.

3. Syahrir, S., Irviani Ibrahim., Syarfaini., Yessy Kurniati., \& Halimatussa'diyyah. 2021. Hubungan BBLR, Kebiasaan Merokok Keluarga, dan Status Gizi dengan Riwayat ISPA Bayi di Kelurahan Ballaparang.

4. Syarfaini., Sukfitrianty Syahrir., Yusma Indah Jayadi., \& Andi Ainun Musfirah. 2021. Hubungan Tipe Pola Asuh dan Perilaku Makan dengan Status Gizi Anak Disabilitas Di SLB Negeri 1 Makassar Tahun 2020.

5. Maesarah., Deysi Adam., Herman Hatta., Lisa Djafar., \& Indriyani Ka’aba. 2021. Hubungan Pola Makan dan Riwayat ASI Ekslusif Dengan Kejadian Stunting Pada Balita Di Kabupaten Gorontalo. 